\title{
Grappling with the bomb: Britain's Pacific H-bomb tests
}

\section{Stewart Firth}

To cite this article: Stewart Firth (2018) Grappling with the bomb: Britain's Pacific H-bomb tests, Global Change, Peace \& Security, 30:2, 277-278, DOI: 10.1080/14781158.2018.1460718

To link to this article: https://doi.org/10.1080/14781158.2018.1460718

$$
\text { Published online: } 21 \text { Apr } 2018 .
$$

Submit your article to this journal ¿

Џll Article views: 47

View Crossmark data ¿ 
BOOK REVIEWS

Grappling with the bomb: Britain's Pacific H-bomb tests, by Nic Maclellan, Canberra, ANU Press, 2017, 383 pp., AU\$55.00 (paperback), ISBN 978-1-76046-137-9

When we think of the nuclear history of the Pacific Islands, we think first of the testing programmes which extended over many years at Bikini and Enewetak in the Marshall Islands (by the Americans) and at Moruroa and Fangataufa in French Polynesia (by the French). Altogether, the USA and France tested nuclear bombs in the Pacific for half a century, 19461996.

The British testing programme at Malden and Kiritimati Islands in what is now Kiribati tends to be forgotten. It lasted less than two years in 1957 and 1958. And the official British account of it - a section of Lorna Arnold's Britain and the $\mathrm{H}-\mathrm{Bomb}^{1}$ - focuses on the technical and the military dimensions of the nuclear trials rather than their impact on the New Zealanders, Fijians, $\mathrm{i}-$ Kiribati and British personnel involved, and on the wider political context of anti-nuclear protest and long term radioactive contamination. Until this book, the British nuclear tests were not truly part of Pacific history, nor had the human story of those tests been told.

Nic Maclellan has brilliantly filled this gap in Grappling with the Bomb, which is not only exhaustively researched but also highly readable, as one might expect from Australia's leading journalist of Pacific affairs. The archival research alone is impressive, in particular in the use of British Colonial Office records from the 1950s, and often highly revealing. But added to that is a wide-ranging research achievement resting on secondary literature, official reports, newspapers and Internet blogs. Most important of all in bringing the story to life are the interviews Nic Maclellan has conducted over a number of years with people from Fiji, Tahiti, the Marshall Islands and other parts of the Pacific.

The construction of the book is cleverly personalised, with chapters focused on a succession of individuals, high and low: from British prime ministers seeking to make Britain great again to Pacific Islanders caught up in a nuclear project that left many ill for the rest of their lives. There is a chapter on the pacifist Harold Steele, who attempted to organise a sailing voyage into the test zone (he failed but inspired many others later), one on the scientist Al Rowland, who demonstrated that there was a higher incidence of leukaemia and multiple myeloma among New Zealand test veterans; and a number of chapters on a succession of representative Fijians - Ratu Inoke Bainimarama, the chief petty officer; Ratu Penaia Ganilau, the high chief; Isireli Qalo, the sapper; and at the end of the book Frank Bainimarama, the present prime minister of Fiji. The book has numerous photographs.

What emerges from this account is a picture of Britain's post-imperial hubris and nuclear ambitions played out as far from home as the British could get. For the British authorities, the great ally of the enterprise was secrecy. When Canberra aircraft flew from Maralinga across the Pacific to Christmas Island in 1957, an RAF Air Commodore noted that the aircraft engines were radioactive:

Aircraft of the No. 76 Squadron flying to Christmas Island and stopping at Nandi and Canton may be radioactive internally... There appears to be no regulations in force governing the transit of radioactive aircraft through international civil airports such as Nandi and Canton.

${ }^{1}$ Lorna Arnold, Britain and the H-Bomb (London: Palgrave Macmillan, 2001). 
The fact that an engine may be 'hot' should be concealed from the Nandi authorities unless they ask. (173)

This is a piece of scholarship that brings the reader up short, with the realisation - known but not fully appreciated - of the extent to which European prejudices and outright racism played a part in events. The Japanese, writes a diplomat in Tokyo back to London, 'are a hysterical people'. If the Japanese were hysterical, the Pacific Islanders were primitive (though closer to Europeans than mice, according to one 'expert'). The British acted on their beliefs about the primitiveness of Pacific Islanders by setting less stringent safety standards for them during the tests: whereas 'civilised populations' were 'assumed to wear boots and clothing and to wash', 'primitive peoples' were assumed not to possess these habits ... It is assumed that in the possible regions of fall-out at Grapple there may be scantily clad people in boats to whom the criteria of primitive peoples should apply' (10).

The truth is that the British military authorities, engaged on a mission of national aggrandisement, did not care much about the so-called 'primitive peoples' affected by it, and were happy to exploit the legendary loyalty of the Fijians and the Royal Fiji Military Forces. Chief Petty Officer Ratu Inoke Bainimarama, whose sailors accompanied him to Malden Island for a test in June 1957, recalled:

We had this thing on called flash gear. You know, it covered our whole bodies. It covered our whole face. There were goggles provided, hand gloves, boots, there was nothing left out. We wore this thing, then they gave us a badge each. They said if anything happened to us this badge will be useful. If our bodies were to vaporise, this badge would not. (130)

Even though the exposed Fijians wore film badges recording their exposure, the British government did not bother to keep this information. Years later it could claim to know nothing about the problem.

The work of many years of research, Grappling with the Bomb is an extraordinarily important contribution to our understanding of the nuclear history of the Pacific and the impositions of late colonialism in a part of the world where the colonial experience is commonly supposed to have been benign. It is a sharp reminder, if any were needed, of the extent to which nuclear testing in the Pacific Islands depended upon their colonial status and the inability of the Islanders therefore to say no, as well as the universally anti-nuclear sentiment that this produced in the region once independence was achieved.

Stewart Firth College of Asia and the Pacific, Australian National University, Canberra, Australia stewart.firth@anu.edu.au

(c) 2018 Stewart Firth https://doi.org/10.1080/14781158.2018.1460718

Check for updates

The Doomsday Machine: confessions of a nuclear war planner, by Daniel Ellsberg, New York, Bloomsbury, 2017, 420 pp., US\$21.00 (hardcover), ISBN 978-1-60819-670-8

The Doomsday Machine provides an inside view of the 'institutionalised madness' ${ }^{1}$ of the US nuclear war machine. Unlike the fictional system featured in the film Dr. Strangelove, Ellsberg

1Daniel Ellsberg, The Doomsday Machine: Confessions of a Nuclear War Planner (New York: Bloomsbury, 2017$), 332$. 